\title{
KROMOSOM TUMBUHAN SEBAGAI MARKA GENETIK
}

\author{
Isna Rasdianah Aziz \\ Jurusan Biologi UIN Alauddin Makassar \\ E-mail: isna-rasdianah@uin-alauddin.ac.id
}

\begin{abstract}
Abstrak: Kromosom bertindak sebagai pembawa materi genetik yang memiliki peran penting dalam proses peningkatan kualitas produk pemuliaan. Kromosom sebagai marka genetik digunakan untuk menganalisis keragaman genetik untuk memperoleh hasil paling tinggi, waktu proses lebih singkat serta tahan terhadap berbagai cekaman biotik dan abiotik. Metode yang digunakan antara lain adalah preparasi kromosom, penyusunan peta karyotype dan karakterisasi kromosom. Perbedaan pada struktur, bentuk dan ukuran kromosom dapat mempengaruhi perbedaan karakter fenotipe antar spesies tumbuhan yang diamati, meskipun tergolong dalam spesies yang sama.
\end{abstract}

Kata Kunci: Karakterisasi kromosom, Kromosom tumbuhan, Karyotype, Struktur kromosom

\section{PENDAHULUAN}

$\mathrm{S}$ tudi kromosom telah dimulai sejak era 1600, sesaat setelah mikroskop ditemukan. Penemuan mikroskop memberikan kontribusi yang besar terhadap kemajuan ilmu kromosom. Struktur kromosom pertama kali diamati oleh Karl Wilhelm von Nägeli pada tahun 1842, sebagai objek yang muncul pada saat pembelahan sel. Tahun 1844, perilaku kromosom pada saat pembelahan sel berhasil dideskripsikan oleh Nägeli dan dinyatakan sebagai deskripsi pertama tentang mitosis. Walther Flemming, 38 tahun kemudian (1882), menciptakan istilah kromatin pada saat pembuatan sketsa proses mitosis pada laporannya. Pada tahun 1888, seorang ahli anatomi, patologi dan embriologi, Heinrich Wilhelm Gottfried von Waldeyer-Hartz, dikenal dengan Wilhelm Waldeyer berkebangsaan Jerman memberikan istilah kromosom (Chromosomen) sebagai benda berwarna (stainable bodies) berdasarkan konsep morfologi anatomi dan susunan benang kromatin yang dijelaskan oleh Flemming. Benda berwarna ini mampu menyerap zat warna dengan baik sehingga terlihat kontras dengan bagian sel lain. Penemuan struktur molekul DNA oleh Watson dan Crick (1953), kemajuan teknik pencitraan kromosom oleh Barbara (1938) dan prosedur sekuensing DNA oleh Sanger dan Coulson (1975), telah memberikan kontribusi yang signifikan dan penemuanpenemuan baru dalam bidang sitogenetika, meliputi ilmu tentang struktur, fungsi, perilaku dan efek kromosom, baik pada tingkat konvensional sampai tingkat pemetaan molekuler modern (Figueroa \& Bass, 2010; Fukui \& Nakayama, 2000; Gill, Hans, \& Jackson, 2008; Paweletz, 2001; Scheuerlein, Henschke, \& Köckerling, 2017). 


\section{STRUKTUR MOLEKULER KROMOSOM TUMBUHAN}

Kromosom merupakan struktur nukleoprotein, membawa materi genetik berupa DNA sebagai unit hereditas serta membawa informasi untuk aktivitas regulasi sel (Crow \& Crow, 2002; Francis, 2007). Genom pada tumbuhan terbagi menjadi kromosom yang terdiri dari jutaan basa DNA. Jumlah kromosom pada tanaman berbunga cukup banyak jika diamati di bawah mikroskop. Berbeda dengan kromosom pada manusia, kromosom pada tumbuhan memiliki variasi sebanyak jumlah spesies yang ada, dapat berbeda dari satu spesies dengan spesies lainnya dan dapat berbeda antara tipe wild (liar) dan kultivar. Hal ini menyebabkan beberapa bagian kromosom tumbuhan sulit dibedakan, sehingga menjadi barrier genetik terhadap aliran genetik antara spesies tersebut (Gur \& Zamir, 2004; Heslop-Harrison \& Schwarzacher, 2011; Husband, 2004). Akan tetapi, dalam penelitian sitologi, beberapa di antaranya telah digunakan sebagai penanda genetik dalam mengidentifikasi kromosom dan memvisualisasikan perubahan struktur kromosom. Perbedaan jumlah dan morfologi kromosom dapat digunakan sebagai data klasifikasi dan hubungan kekerabatan dalam tingkat familia (Aristya et al., 2015).

Fungsi utama kromosom adalah bertanggung jawab pada pemisahan DNA dalam jumlah yang sama dan memastikan bahwa keturunan membawa sifat dari kedua orang tua pada setiap pembelahan sel (Bass \& Birchler, 2011). Di samping itu, kromosom juga menjaga integritas dan ketepatan replikasi genom pada setiap siklus sel. Kromosom memiliki tiga elemen struktur utama yang diperlukan untuk replikasi dan pemeliharaan: sentromer, telomer dan unit replikasi. Struktur kromosom membantu memastikan DNA tetap melilit pada protein.

Sentomer merupakan daerah kontriksi (lekukan) primer di bagian tengah kromosom yang bersifat khusus dan tetap, berfungsi sebagai titik perlekatan spindel mikrotubul yang bertanggung jawab dalam pergerakan kromosom saat pembelahan sel. Sentromer juga digunakan sebagai tempat melekatnya sister kromatid. Peranan sentromer merupakan komponen kunci dalam proses segregasi kromosom. Sentromer ditandai oleh adanya DNA repetitif (sekuen nukleotida yang berulang-ulang). Dalam pembelahan sel, DNA repetitif pada sentromer berperan memisahkan kohesi antar sister kromatid dan mengatur kromatin pada nukleus saat interfase (LPidoux \& CAllshire, 2000). Nonomura \& Kurata (2001) dalam penelitiannya menyatakan bahwa sentromer pada padi terdiri dari beberapa sekuens repetitif dengan klaster tandem RCS2 yang kemungkinan berperan sebagai inti dari fungsi sentromer dengan panjang mencapai ratusan megabase.

Telomer memiliki peranan penting dalam melindungi ujung pada kedua lengan kromosom, yang ditandai dengan adanya urutan nukleotida yang khas (Gambar 1). Urutan nukleotida tersebut berulang dan bersifat spesifik pada tiap spesies yang berperan sebagai struktur healing dan pelindung nucleoproteinaceous pada kebanyakan telomer tumbuhan. Sama halnya dengan sentromer, pada telomer juga ditemukan DNA repetitif. DNA repetitif pada telomere mengikat protein yang melindungi ujung kromosom dari degradasi serta mencegah gen hilang pada saat DNA memendek setelah satu putaran replikasi (Gill et al., 2008; Shapiro \& Sternberg, 2005).

Unit replikasi terdapat pada lekukan kedua kromosom yang berada di sepanjang lengan disebut dengan NOR (Nucleolar Organizing Regions). NOR terdiri dari gen rRNA 5.8S, 18S dan 28S yang terbentuk selama interfase. Gen-gen ini membawa ekspresi yang berbeda. 
Pada prometafase mitosis, sifat kromosom secara morfologi lebih stabil dibandingkan meiosis. Struktur kromosom seperti sentromer, telomere, satelit dan lainnya akan terlihat lebih jelas, sehingga kromosom pada fase ini digunakan sebagai marka genetika, khususnya pada tumbuhan yang dapat dianalisis dengan berbagai macam metode.

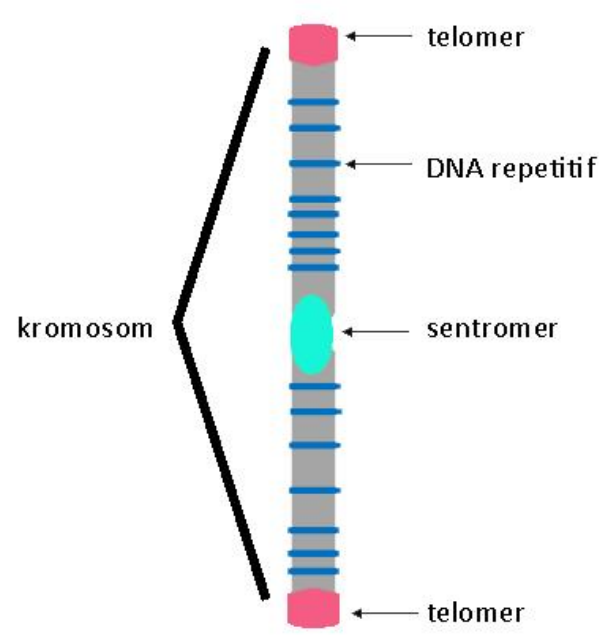

Gambar 1. Representasi struktur kromosom tumbuhan

\section{KROMOSOM SEBAGAI MARKA GENETIK}

Program pemuliaan tanaman saat ini terus mengalami kemajuan. Rekuisisi bibit unggul dengan kapasitas hasil paling tinggi, proses lebih singkat serta tahan terhadap berbagai cekaman biotik dan abiotik menjadi rebutan pangsa pasar. Perakitan bibit unggul untuk membentuk varietas baru mutlak dilakukan. Keberhasilan program tersebut tidak terlepas dari pembentukan dan peningkatan keragaman genetik untuk seleksi dan bahan persilangan dan proses uji individu unggul sebelum varietas baru dilepas (Pardal, 2014). Keragaman genetik dapat dianalisis dan dihasilkan melalui proses introduksi, poliploidisasi, hibridisasi, seleksi, bioteknologi dan mutasi (mutasi alami dan induksi).

Kemajuan teknik marka genetik memberikan kemudahan dalam berbagai kegiatan pemuliaan. Pemetaan kromosom yang mampu mengendalikan karakter kualitatif dan kuantitatif menjadi perhatian pemulia. Kromosom sebagai marka genetik dapat digunakan untuk menganalisis keragaman genetik berdasarkan susunan kromosom. Metode yang digunakan dalam analisis ini di antaranya adalah metode preparasi kromosom, peta karyotype dan karakterisasi kromosom.

\section{PREPARASI KROMOSOM TUMBUHAN}

Proses preparasi kromosom merupakan kegiatan pembuatan preparat kromosom tumbuhan yang sedang aktif membelah. Kromosom dapat terlihat jelas pada fase-fase 
tertentu seperti metafase dan prometafase pada saat pembelahan inti (Muhlisyah et al., 2014). Prinsip preparasi kromosom adalah memperoleh sel pada berbagai fase dengan cara menghentikan aktivitas pembelahan sel dengan metode tertentu (Pack \& Stratakis, 2002). Metode preparasi untuk melihat aktivitas sel pada mitosis berbeda dengan meiosis, baik pada sel, tahapan dan reagen yang digunakan pada saat preparasi (G. R Aristya et al., 2015). Metode yang umum digunakan adalah metode squash (pemencetan ujung akar).

Prinsip metode squash adalah mempertahankan sel tetap berada pada prometafase mitosis dengan pemencetan yang tepat dengan menggunakan jaringan somatis dan reagen tertentu. Tahapan squash dimulai dengan:

1. Tahap perkecambahan dan pemotongan ujung akar. Proses perkecambahan benih dapat menggunakan medium tanah dan aquadest. Setelah tumbuh akar dengan panjang sekitar $0,5 \mathrm{~cm}$, maka dilakukan pemotongan ujung akar dimulai pukul 08.00-12.00 untuk mengetahui waktu mitosis tumbuhan yang diamati.

2. Fiksasi. Fiksasi dilakukan dengan memotong ujung akar yang masih muda dan dimasukkan ke dalam botol flakon dan ditambahkan larutan asam asetat glasial $45 \%$ selama 15 menit pada suhu $4^{\circ} \mathrm{C}$. Fiksasi dilakukan dengan tujuan untuk mempertahankan komponen dari sel-sel tumbuhan sehingga tetap dalam keadaan hidup (lama proses dan suhu yang digunakan berbeda tiap spesies).

3. Tahap maserasi. Proses maserasi dilakukan dengan menggunakan larutan $\mathrm{HCl} 1 \mathrm{~N}$ selama 15 menit dengan suhu $55^{\circ} \mathrm{C}$ dalam inkubator (lama proses dan suhu yang digunakan berbeda tiap spesies). Maserasi bertujuan untuk melisiskan lamela tengah.

4. Tahap pewarnaan. Proses pewarnaan dilakukan pada bagian ujung akar yang telah dimaserasi dan dibersihkan. Tahap pewarnaan menggunakan larutan aceto-orcein $1 \%$ selama 20 menit pada suhu kamar, yang bertujuan memberikan warna lebih gelap pada kromosom, sehingga memudahkan pengamatan.

5. Tahap pemencetan (squash). Proses pemencetan dilakukan setelah potongan ujung akar terwarnai lebih gelap. Cuplikan dari ujung akar diletakkan pada gelas preparat dan ditetesi gliserin sebelum ditutup dengan gelas penutup. Pemencetan dilakukan dengan menggunakan ujung pensil/kuas kayu dan diberi kuteks untuk melekatkan tepi gelas. Preparat disimpan dalam lemari pendingin suhu $4^{\circ} \mathrm{C}$. Squash bertujuan untuk menipiskan sel agar sel menyebar dengan baik.

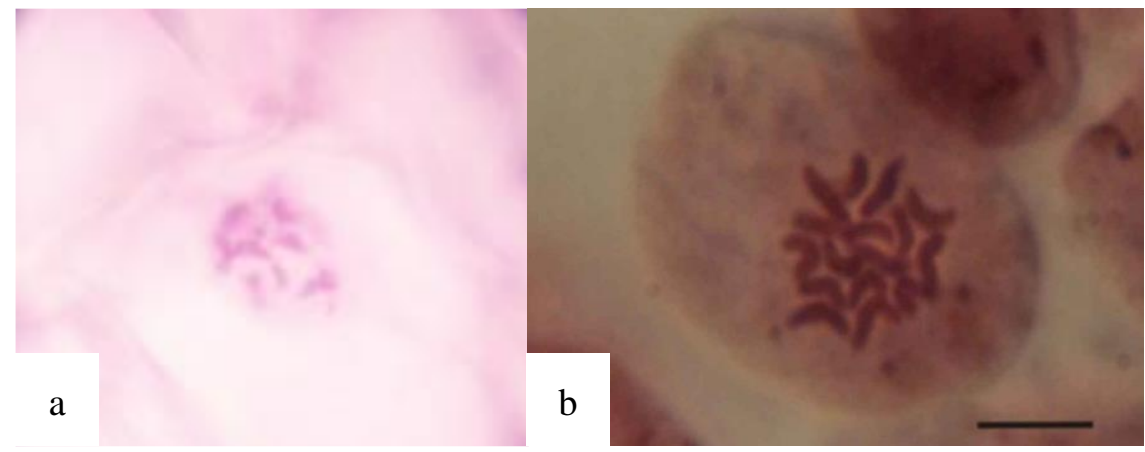

Gambar 2. a) Prometafase pada akar markisa ungu (Passiflora edulis) $10 x 100 ; b)$ prometafase pada Indigofera tinctoria ((Muhlisyah et al., 2014)

Pada beberapa tumbuhan dengan ukuran dan kromosom yang kecil, metode squash yang menggunakan aceto-orcein membutuhkan bantuan mikroskop resolusi tinggi. 
Kromosom yang tidak melekat erat pada gelas benda dan tidak tersebar akibat pemencetan yang tidak tepat mengakibatkan sel relatif masih berada pada bentuk aslinya, sehingga gambar menjadi tidak efektif (Etikawati \& Setyawan, 2000).

\section{PETA KARYOTIPE DAN KARAKTERISASI KROMOSOM}

Dalam penataan kromosom, karyotype mampu mencakup variasi antar spesies. Jika terdapat beberapa genus tumbuhan yang memiliki banyak spesies, maka data morfologi dan ekologi tidak cukup merepresentasikan hubungan filogenetik antar spesies tersebut. Akan tetapi, sitotaksonomi mampu menjadi jembatan yang akurat untuk mempelajari hubungan filogenetik tersebut (Venora et al., 2008).

Jumlah, bentuk, ukuran kromosom dan posisi sentromer pada kromosom tumbuhan bersifat khas, sehingga memudahkan proses karakterisasi kromosom pada spesies. Karakterisasi kromosom tersebut ditampilkan dalam bentuk karyotype atau karyogram sebagai susunan lengkap pasangan homolog yang disusun dalam seri kromosom dari yang terbesar hingga terkecil. Pasangan kromosom yang digambar tunggal disebut ideogram. Parameter yang diamati dalam penyusunan karyotype antara lain: panjang kromosom, jumlah kromosom, posisi sentromer, ukuran dan posisi satelit, ukuran dan posisi lekukan sekunder, derajat dan distribusi heterokromatin, perbandingan pasangan kromosom terpanjang dan terpendek, serta perbandingan lengan panjang dan pendek.

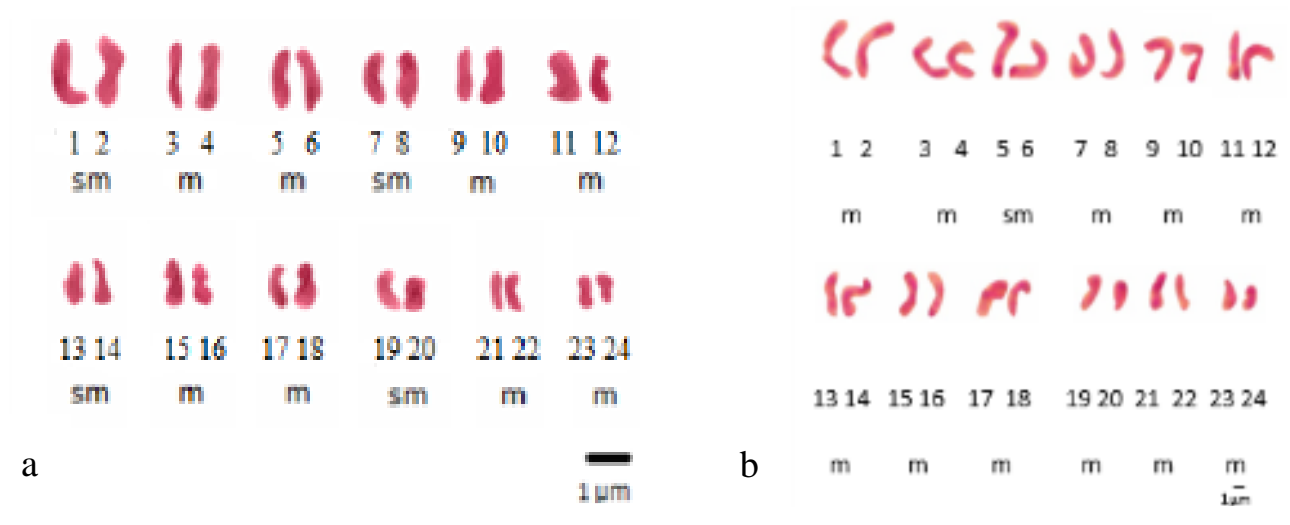

Gambar 3. a) Karyotype kromosom paprika (Capsicum annum var. Grossum L.) Red Star; b) karyotype kromosom terong putih (Solanum melongena L.) Pulus (Aristya et al., 2019)

Peta karyotype dapat dibuat dengan cara konvensional dengan membandingkan dua foto/gambar kromosom prometafase yang sama dengan fokus yang berbeda. Foto tersebut digambar ulang di atas kertas transparan (dijiplak), digunting dan diatur sesuai bentuknya. Jumlah kromosom dan panjang kedua lengan kromosom diukur dan kromosom dipasangkan dengan homolognya. Dengan sistem komputasi, gambar kromosom pada prometafase yang terbaik dipilih, diukur dan dipotong sesuai pada saat pengamatan, kemudian diolah dengan menggunakan program Adobe Photoshop, Corel Draw dan Image Raster dengan cara mengurutkan kromosom dengan panjang absolut terpanjang sampai terpendek. Karyotipe ini menjadi acuan dalam pembuatan idiogram (Aristya et al., 2019). 
Data karyotype digunakan untuk melakukan karakterisasi kromosom dengan parameter antara lain: jumlah kromosom, panjang lengan pendek kromosom (p), panjang lengan panjang kromosom (q), panjang lengan absolut kromosom (p+q), indeks sentromer (IS), rasio panjang lengan panjang dengan lengan pendek (RLK) dan rasio panjang kromosom absolut terpanjang dan terpendek. Panjang $\mathrm{p}$ dan $\mathrm{q}$ dapat dilakukan dengan pengukuran menggunakan software AutoCAD Map. Kemudian IS dan RLK dapat dikalkulasi melalui Microsoft excel. Pengukuran IS dan RLK dilakukan untuk mengklasifikasi bentuk kromosom berdasarkan letak sentromer.

\section{KESIMPULAN}

Metode preparasi kromosom, penyusunan peta karyotype dan karakterisasi kromosom adalah metode yang dapat digunakan untuk mengetahui struktur, bentuk, jumlah dan ukuran kromosom. Perbedaan pada struktur, bentuk dan ukuran kromosom dapat mempengaruhi perbedaan karakter fenotipe antar spesies tumbuhan yang diamati, meskipun tergolong dalam spesies yang sama.

\section{DAFTAR PUSTAKA}

Aristya, G. R, Daryono, B. S., Handayani, N. S. N., \& Arisuryanti, T. (2015). Karakterisasi kromosom tumbuhan dan hewan. Yogyakarta: Gadjah Mada University Press.

Aristya, Ganies Riza, Zuyyina, C., Febiansi, D., Ayuningsih, R., Prasiwi, K. D., Nurwijayanti, T. A., ... Renaldy, B. (2019). Karakterisasi Kromosom Spesies Anggota Familia Solanaceae. BIOTROPIC, 3(1), 24-38.

Bass, H. W., \& Birchler, J. A. (2011). Plant cytogenetics: Genome structure and chromosome function (Vol. 4). New York: Springer Science \& Business Media.

Crow, E. W., \& Crow, J. F. (2002). 100 Years Ago: Walter Sutton and the Chromosome Theory of Heredity. Genetics, 160(1), 1-4.

Etikawati, N., \& Setyawan, A. D. (2000). Studi Sitotaksonomi pada Genus Zingiber. Biodiversitas, 1(1), 8-13. https://doi.org/10.13057/biodiv/d01002

Figueroa, D. M., \& Bass, H. W. (2010). A historical and modern perspective on plant cytogenetics. Briefings in Functional Genomics, 9(2), 95-102. https://doi.org/https://doi.org/10.1093/bfgp/elp058

Francis, D. (2007). The plant cell cycle - 15 years on. New Phytologist, 174(2), 261-278. https://doi.org/https://doi.org/10.1111/j.1469-8137.2007.02038.x

Fukui, K., \& Nakayama, S. (2000). Plant Chromosomes: Laboratory Methods. London: CRC Press.

Gill, N., Hans, C. S., \& Jackson, S. (2008). An overview of plant chromosome structure. Cytogenet Genome Res, 120, 194-201. https://doi.org/10.1159/000121067

Gur, A., \& Zamir, D. (2004). Unused Natural Variation Can Lift Yield Barriers in Plant Breeding. PLoS Biology, 2(10), e245. https://doi.org/https://doi.org/10.1371/journal.pbio.0020245

Heslop-Harrison, J. S. (Pat), \& Schwarzacher, T. (2011). Organisation of the plant genome in chromosomes. The Plant Genome: An Evolutionary View on Structure and Function, 66(1), 1833. https://doi.org/https://doi.org/10.1111/j.1365-313X.2011.04544.x

Husband, B. C. (2004). Chromosomal variation in plant evolution. American Journal of Botany, 91(4), $621-625$. 
LPidoux, A., \& CAllshire, R. (2000). Centromeres: getting a grip of chromosomes. Current Opinion in Biology Cell, 12(1), 308-319. https://doi.org/https://doi.org/10.1016/S0955-0674(00)00094-6

Muhlisyah, N., Muthiadin, C., Wahidah, B. F., \& Aziz, I. R. (2014). Preparasi Kromosom Fase Mitosis Markisa Ungu (Passiflora edulis) Varietas Edulis Sulawesi Selatan. Biogenesis: Jurnal Ilmiah Biologi, 2(1), 48-55. https://doi.org/https://doi.org/10.24252/bio.v2i1.467

Nonomura, K.-I., \& Kurata, N. (2001). The centromere composition of multiple repetitive sequences on $\begin{array}{llll}\text { rice } & \text { chromosome } & \text { Chromosoma, } & \text { 110(4), }\end{array}$ https://doi.org/https://doi.org/10.1007/s004120100148

Pack, S. D., \& Stratakis, C. A. (2002). Chromosomes: Methods for Preparation. In Encyclopedia of life sciences (pp. 1-3). Maryland: Macmillan Publishers Ltd.

Pardal, S. J. (2014). Teknik Mutasi untuk Pemuliaan Tanaman. Balai Besar Penelitian Bioteknologi dan Sumberdaya Genetik Pertanian. Retrieved from http://biogen.litbang.pertanian.go.id

Paweletz, N. (2001). Walther Flemming: pioneer of mitosis research. Nature Reviews Molecular Cell Biology, 2(1), 72-75. https://doi.org/10.1038/35048077

Scheuerlein, H., Henschke, F., \& Köckerling, F. (2017). Wilhelm von Waldeyer-Hartz: A Great Forefather: His Contributions to Anatomy with Particular Attention to "His" Fascia. Front Surg, 4, 74. https://doi.org/10.3389/fsurg.2017.00074

Shapiro, J. A., \& Sternberg, R. von. (2005). Why repetitive DNA is essential to genome function. Cambridge University Press, 80(2), 227-250.

Venora, G., Ravalli, C., \& Cremonini, R. (2008). The karyotype as a tool to identify plant species: Vicia species species belonging to Vicia subgenus. Caryologia, 61(3), 300-319. https://doi.org/https://doi.org/10.1080/00087114.2008.10589642 